\title{
PREDIKING: ESKATOLOGIESE TRANSFORMATOR EN ALARMSINJAAL
}

\author{
P.W. Bingle en \\ Jan J. van der Walt \\ Departement Diakoniologie \\ Potchefstroomse Universiteit vir $\mathrm{CHO}$ \\ POTCHEFSTROOM
}

\begin{abstract}
Due to the interlocking of the old and the new eeon, preaching contains on eschatological tension and it projects an eschatological prefiguration in the existing old dispensation. Preoching the kingdom of God in its eschatological perspective is consequently not simply a matter of supptying interesting data about the last locus of dogmatics and what will happen at the end of times. Proclaiming Jesus Christ as the Eschatos constitutes preaching as an eschatological maturing process. The remembrance of the perfecto fulfilled by Christ invokes the futuro which is yet to come. Eschatology offers to preaching an actuality and an existential moment in the timespan of every doy. With regard to this, preaching the Word - Dabow - of God, which has an eschatological preference and which is criticalty associated with the proton as the yet incomplete world, opens a vision on the novum of the kingdom of God. Eschatology also projects an alignment with and a praeludium to the etemal judgment of God. Henceforth, preaching is an act of God's clarion call to "prepare to meet your God" (Amos 4:12). Proclaiming the eschatological judgment, preaching transforms the viva vax of the Deus loquens to the language and environment of the target audience. The preacher is God's interpreter in the language zones of man.
\end{abstract}

\section{INLEIDING}

\section{$1.1 \quad$ Probleemstelling}

Die nood en die problematiek van die prediking is wanneer die viva vox van die Deus loquens nie tot spraak kom nie en die Woord-Dabar - nie meer die Leilmotiv is nie (Jonker, 1962:121). Dit is die gevolg van prediking wat nie die diepste polariteit en hoogspanning waarmee die prediker te doen het - die verhouding: ewige Woord van God en die in die Heilige Skrif opgenome woorde - verdiskonteer nie. Daarmee gaan ook die aktualiteit van die prediking verlore. Wanneer hierdie onderskeid geminimaliseer word of nie eerbiedig word nie en as identies in betekenis saamval, is die prediking onder andere skuldig aan bibliolatrie. Dan word van die Bybel ' $n$ 'afgod' gemaak en dit terwyl nie die Woord van God nie, maar die God van die Woord aanbid moet word. En dit is juis $\mathrm{Hy}$, die lewende God, wat die eskaton laat kom en in die vleesgeworde Woord die Eskatos is. 
In hierdie artikel word getrag om na te gaan wat die draagwydte vir die prediking is van die feit dat Christus die Woord en die Eskatos is.

\subsection{Aktualiteit}

Prediking met sy perspektief op die ewige lewe is nie 'n eskatologiese fantasie wat vreemd aandoen en alleen as toekomsmusiek bekoring en aktualiteit besit nie. Die eskatologiese perspektief op die ewige lewe is die verborge stimulus wat in die daaglikse lewe indring en konkrete gestalte moet kry. Dit is die eskatologiese motief wat motiveer en inspireer om in gehoorsaamheid aan God en sy Woord te boetseer aan die tans nog onbekende gestalte van die naderende toekoms sonder om te spekuleer. Calvyn (vgl. Douma \& Van der Vegt, s.a.:18) waarsku dat oor die toekoms allerlei fantasieë bygevoeg kan word (vgl. ook Nürenberger, 1987:105-109). Dit hoort nie in die prediking nie. "Als men den weg naar den hemel maar gaat! Dan zullen we later wel zien hoe de heerlijkheid des hemels is." Prediking met hierdie visie se aktualiteit is onder andere gelcë in sy aanmoedigende en bemoedigende aard en kwaliteit omdat "julle weet dat julle inspanning in diens van die Here nie tevergeefs is nie" (11 Kor. 15:58). Arbeid en lewensroeping so verrig, ontvang heiligende vervulling in die teenwoordigheid van die Drie-enige God. Dit is 'n lewe coram Deo.

\section{Metode}

Aan die hand van besinning oor die onderwerp word van die veronderstelling uitgegaan dat die eskatologie nie slegs maar 'n verkondiging van die 'laaste dinge' is of 'n laaste hoofstuk (locus) van die dogmatiek nie. Dit sou 'n onhoudbare en skadelike verenging meebring. 'n Onderskeid word gemaak tussen 'n realistiese, futuriese en futuristiese eskatologie. Aan die hand van tersaaklike literatuur word in die lig van die Heilige Skrif getrag om perspektiewe te open op die plek en die noodsaak van die eskatologie in die prediking.

\section{PREDIKING: TRANSFORMATOR VAN ESKATOLOGIESE HOOG- SPANNING}

\subsection{Die Woord is Dabar van die Dews loquens}

Daar is ' $n$ merkwaardige polariteit in en rondom die Heilige Skrif, tussen die ewige Woord van God en die op skrif gestelde woorde in die Bybel. "Deze polariteit is een correlatie: de een mag nooit van de ander gescheiden worden, maar ook niet met de 
ander vereenzelwigd worden" (Jonker, 196-:52). Die onderskeid kan so onder woorde gebring word: die Woord van God as ewige Logos - Dabar - is mér as die Heilige Skrif. Wel kan gesê word: die Heilige Skrif is God se Woord, maar daar kan nie gesê word dat die Woord van God die Skrif is nie. God spreek sy Woord in en deur die Skrif. Die Woord van God deurdring en omspan die Heilige Skrif.

Die Woord wat God spreek en waardeur die geloof tot stand gebring en begrond word. is nie die mededeling van algemene waarhede van een "metafysisch document" nie (Berkouwer, 1967:393). Die Woord van God is die dinamies-lewende aktiwiteit van God Self terwyl die Skrif 'n statiese gegewe van vaste woorde en sinskonstruksies is waaraan niks verander mag word nie. Wie dit doen, knoei. Om te dink aan die Woord van God, is denke aan God self, sy selfbekendmaking aan die mens. "Het Woord Gods is de uitdrukkingsmogelijkheid van God in spreken en handelen. Door het Woord, Dabar, daadwoord, werkt God door de geschiedenis heen" (Jonker, 196-:52). Die gesag van die Skrif is dus die gesag van God se lewende Woord en daarmee die gesag van die Deus loquens self. Daarom kan prediking nie maar bloot 'n historiesargeologiese in herinnering roep van gefikseerde metafisiese waarhede wees nie. Prediking is 'n profeties-eskatologies-keurende proklamering.

Bo die Heilige Skrif staan nòg die belydenis, nog die kerk, nog die teologie, maar die Woord - Dabar - van God wat die Heilige Skrif in gebruik neem en deur vertolking en prediking die mensheid in sy geskiedenis begelei.

De Schrift is zonder het Woord blind, het Woord is zonder de Schrift leeg. Dat houdt in dat wij van het geheel van het Woord Gods wel kunnen komen tot de delen van de Heilige Schrift, maar dat wij nooit vanuit de delen van de Heilige Schrift kunnen opklimmen tot de totaliteit van het Woord Gods (Jonker, 196-:53).

Wie só die verband tussen die Woord van God en die Heilige Skrif onderken en vashou, word daarvan bewaar om die Skrifwoorde eiemagtig los van die lewende God in sy heilsopenbaring te gebruik en te misbruik (bibliolatrie). Die eiemagtigheid kom aan die dag as die mens met sy logika oor die Skrifwoorde wil beskik/besluit/bepaal, én as die mens eie gekose relasie/verbande aanbring tussen die Bybelse gegewens. Dan word die Skrifwoorde nie meer gesien as geskrewe uitdrukkinge van die Woord van God wat dinamies en skeppend agter en in die Skrif besig is en deur die Heilige Gees die Skrif tot aktuele Woord van God verlewendig nie.

Die Bybel het in die tyd ontstaan en wens ook self om so gelees en geïnterpreteer te word, terwyl die Woord, Dabar, ewig is. Nêrens identifiseer die Bybelwoord "als zodanig zich met het Woord Gods, telkens wijst de Bijbel zelf terug en heen naar de arbeid van de Logos, het Woord" (Jonker, 196-:544). Voorbeelde: Die Bybel vermeld hoe die Woord skeppend werksaam is (Gen. 1:1-3), hoe die Woord deur die profete tot 
Israel gekom het - 'So spreek die Here' - (vgl. Van Rooy, 1988:49-63) hoe die Woord oorweeg en oorpeins is (chokmatiese literatuur), hoe die Woord besing en geprys is (Psalms), hoe die Woord vlees geword het in Jesus Christus (Joh. 1:1,14), hoe Hy die Woord as die nuwe daad van God, naamlik van kruis en opstanding, hemelvaart, Pinkster en wederkoms deur die apostels laat verkondig het.

\subsection{Die Woord (die Logos) is dinamies}

In die Bybel kom die Woord in die bonte menigte van die samelewing van die oudheid aan die woord. Maar is die Woord van God slegs 'n gebeure, 'n aktivering, 'n gestalte-

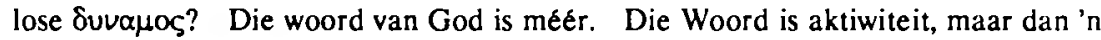
heilsaktiwiteit wat hom rig op skepping, ontdekking, verlossing en bestemming, en : "... dit zijn de 'categorieën' van het Woord Gods, van waaruit de Schrift benaderd wordt en van waaruit de Schrift ook in de moderne prediking nog steeds gepredikt wordt!" (vgl. Jonker, 196-:53). In die prediking kom die Woord wat in en deur die Heilige Skrif aan die Woord kom, opnuut aan die woord in die situasie van die hede.

Achter de Heilige Schrift staat de daadkracht van het Woord, de daden van de schepping, verkiezing, verzoening, verlossing, heiliging, verheerlijking, daden, die geschieden door het Woord en vertolkt worden door de Heilige Schrift. Door deze visie van de soevercine gang van het Woord Gods met en in de mensheidsgeschiedenis wordt juist de actuele kracht van de Heilige Geest in de Heilige Schrift tot uitdrukking gebracht. Achter de Heilige Schrift wordt de levende adem van God onderkend (Jonker, 196-54).

Die vervulling en doelbewerking van dit alles reik steeds na die eskatologiese voleinding. Wat deur die gang van die heilsgeskiedenis gebeur het en wat Jesus aan die kruis volbring het om God se Raad te verwesenlik, eindig nie daar nie. Daarom sal die prediking nie die kruis en die opstanding preek as die finale einde nie. "Die tipologie staan van Genesis tot Openbaring oop na die voleinding" (Van der Walt, 1989:59; vgl. ook Trimp, 1986:50; Schmidt, 1987:438-440; Bingle, 1988:1-441). Dit is 'n voleinding wat daarop gerig is om die vrederaad te voltooi en die versoening tot sy volle $\tau \in \lambda \circ$ se $_{\text {te }}$ bring wanneer Christus die koningskap aan God die Vader oordra nadat Hy alle bose magte vernietig het (vgl. 1 Kor. 15:22-28). In die opstanding van Christus is die eskaton gerealiseer en deur die Gees word die eskaton gerealiseer (vgl. Versteeg, 1971:520) - 'n realisering wat nie Christosenties maar teosentries is (vgl. Van der Walt, 1989:59-60). 


\subsection{Kontinuĩteit en diskontinuīteit tussen proton en eskaton}

Dit is die dinamiese daadkrag van die Woord as ewige Logos wat van prediking 'n onrustige aktiwiteit maak. Dit plaas die prediking in 'n hoogspanningstroom - met 'n angsvolle polariteit na kontinuïteit en diskontinuïteit tussen die proton (as eerste gawe) en die eskaton (as laaste gawe). Die koms van die koninkryk is die "in elkaar grijpen van de aeonen" (Ridderbos, 1966:50); dit is 'n "dinamiese kragontplooing" (Van Wyk, 1986:229) en het 'n "eskatologiese momentum" (Louw, 1984:39). Die koms van die koninkryk - en daarmee ook die verkondiging van die koninkryk - "gaat door een onvoorspelbare crisis en vernieuwing heen" (Berkhof, 1968:31). Hierdie hoogspanningstroom, hierdie dinamiese kragontplooing en eskatologiese momentum moet deur die 'transformator' van die prediking gaan. Dit is 'n hoogspanning wat in besonder opgewek word deur die eskatologiese 'stroom' wat deur die prediking gaan.

Die eskatologiese 'stroom' - wat in eskatologies-keurende prediking gestalte moet vind - is gerig op die ontdekking van die novum wat die koninkryk van God aanbring. Die oorvleueling van die aeone plaas die prediking in 'n spanningsveld (vgl. Bingle, 1988:208-310) en maak van die prediking self ook die bewerker van die oorvleueling en die spanning.

In die prediking vind die oormekaarskuif van die aeone plaas. Prediking is die 'inpreek' van die eskaton in die eksistensie. Daarom is daar nie so iets soos 'pasklaar preke' uit die hemel nie. Prediking is nie "blote repetisie van die verlede nie, en ook nie ontdooing van bevrore waarhede nie, maar die blootlegging van Gods Woord in sy gerigtheid op en aktualiteit vir die tyd waarin ons vandag lewe" (Heyns, 1973:166). Dit gaan om konkrete mense (gemeente) wat lewe in 'n konkrete geskiedenis en werklikheid met konkrete vrae en versoekinge. Hiér meld die vraag na God en na geloof hom aan en hier moet dit beantwoord word. Die prediker moet daarom in die oopte van die lewenswerklikheid gaan staan en telkens weer besin vanuit die Skrif: wat wil die viva vox Deus van die Deus relevans hier en nou aan die mens sê in sy onderweg wees, en hoe moet dit gepreek word? Die "Präesentialiteit" (Konrad, 1963:518) van die Skrif moet spreek. Daarom moet die prediker nie alleen Bybelkenner nie, maar ook eietydse verkenner wees (vgl. Bingle, 1986:151-159).

\subsection{Die eskaton aksentueer die proton}

"Vir die gelowige het die ewigheid reeds begin, die ewigheid in die tyd" (Snyman, 1977:270). Eskatologies georiênteerde prediking sal dus nie die lewe in die tussentyd vanuit die toekoms devalueer nie. Te midde van alle begrensinge deur die 'nog nie' is 
die waarde van die tussentyd aangedui. Beklemtoning van die hede ten koste van die toekoms en omgekeerd, relativeer dan die aandag vir die toekoms, of omgekeerd vir die hede (vgl. Wessels, 1987:183-202). As Paulus sy eskatologiese prediking in 1 Korintiërs 15 afsluit, voeg hy onmiddellik daaraan die oproep toe om "standvastig, onwankelbaar, altyd oorvloedig in die werk van die Here (te wees) omdat julle weet dat julle inspanning in diens van die Here nie tevergeefs is nie" (1 Kor. 15:58).

Van sinloosheid in die prediking kan alleen sprake wees vanuit die 'eskaton' van die dood, die ongevulde eskaton van die vervreemding van God wat die Koning van die eeue is. Sulke prediking moet lei tot die onontwykbare konsekwensie "laat ons eet en drink, want môre sterf ons!" (1 Kor. 15:32). Maar die werklike en ware eskaton lei tot prediking wat inspireer en motiveer tot 'n nuwe belangstelling vir die aardse lewe in die tussentyd. Dit is prediking waarin die oproep klink om in verwagting te lewe en die beste gebruik te maak van elke geleentheid (vgl. Ef. 5:16). Dit gaan om 'n handelswyse ten opsigte van die kapoL om 'n "intensives Kaufen, das die vorhandene Möglichkeiten ausschöpft" (Delling, 1938:456). En dit moet geskied ondanks die feit dat die dae boos is, maar ook omdat die dae boos is (Ef. 5:1 6).

Beklemtoning van en uitsig op die nie-ydele en nie-tevergeefsheid van die aktiwiteite in die tussentyd, is nie prediking wat die eskatologiese verwagting nie ag nie. Dit is eerder' $n$ konsekwensie en manifistasie daarvan. Vanuit die eskatologiese verwagting kom daar ruimte vir die roeping om, solank dit dag is, te werk (vgl. Joh. 9:4) en word die mens tot alle goeie werke volkome toegerus (vgl. 2 Tim. 3:17). Vergelyk ook die eskatologiese uitsig en daarom die volle taakaanvaarding in 2 Timoteus 4:1,5 en Tessalonisense 5:8-9. As Paulus hom rig tot die Tessalonisense wat begin leef het asof die dag van die Here al hier is (vgl. 2 Tess. 2:2), beklemtoon hy die 'nog nie' van die eskaton teenoor hulle 'reeds'. Hy doen dit om die tot stilstand gekome lewe weer aan die gang te kry. Eers moet die afval kom en die wettelose mens sy verskyning maak (vgl. 2 Tess. $2: 3$ ). Dit beteken egter nie dat hy die groot aktualiteit van die eskatologie relativeer of dat by hom die gedagte van ' $n$ veraf wederkoms bestaan nie. Hy weet immers ook "die geheime krag van die wetteloosheid is al (reeds) aan die werk" (2 Tess. 2:7). Dit gaan vir Paulus nie om 'n verre toekoms nie, maar om 'n ophande wees van ' $n$ ingrypende en 'n eskatologies beslissende gebeure, "de parousie van de antichrist" en "de parousie van de Heer, die de wetteloze zal doden" (Berkouwer, 1963:49). Paulus wys nie die aktualiteit van die verwagting af nie, maar die stilsit van die verwagting deur ' $n$ voldonge 'reeds'. Vir die prediking beteken dit die oproep tot permanente waaksaamheid in die hede op weg na die toekoms. Die eskaton aksentueer die proton. 


\subsection{Hoogspanning tussen die 'reeds' en die 'nog nie' van die eskaton}

Prediking in die tussentyd aan mense wat "nog nie by die Here woon nie" ( 2 Kor. 5:6) is wel ryk aan bemoediging, ("... ons is altyd vol moed [en] ... ons is vol moed"; 2 Kor. $5: 6,8)$, maar dit is prediking wat tegelyk ook vervul is met die uitsig op "die heerlikheid wat God vir ons in die toekoms sal laat aanbreek" (Rom. $8: 18$ ). Met hierdie ingeboude hoogspanning tussen die 'reeds' en die 'nog nie' het die prediking voortdurend te make. Daaraan kan nie ontsnap word nie. Hierdie spanning kom die duidelikste aan die orde wanneer agtereenvolgens geluister word na die woorde van triomf waarmee die oorwinning van Christus geteken word en daarna die woorde vol verwagting van die eskatologiese onttroning van die dood as laaste vyand (vgl. 1 Kor. 15:26).

Dink hier aan die kras woorde van Paulus dat Christus die bose magte ontwapen

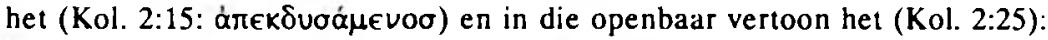

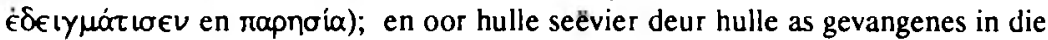

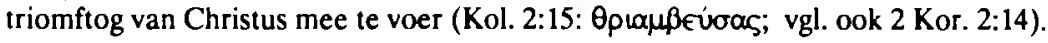
So radikaal en finaal klink hierdie woorde - soos wanneer Paulus skryf dat Christus

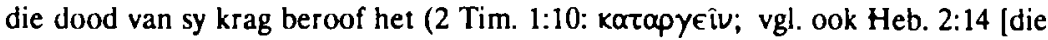
onttroning van die duiwel]) dat dit ondenkbaar is om hier aan te neem dat hiermee nog nie alles gesê is nie.

En tog is alles hiermee nog nie gesê nie. Dieselfde woord katapyeî wat beteken "bedeutungslos machen, ausser Kurz setzen" (Delling, 1933:453; 1 Kor. 1:28) kan ook gebruik word vir die eskatologiese 'onttroning' van die dood as die laaste vyand sodat die spanning van die 'reeds' en die 'nog nie', hier ook terminologies sigbaar word. Daar kan nie aan ontkom word om van 'n 'reeds' én 'n eksklusiewe 'plus' as 'n reële werklikheid te spreek nie. Met nadruk is die onttroning reeds 'n feit: die ontwapening,

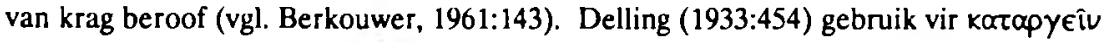
krasse en juiste tipering: "gänzlich wirkunglos" (vgl. 1 Kor. 1:28) en spreek dan hoe kan dit anders? - in verband met die onttroning van die dood van "völlige Vernichtung". Van hieruit dan weer oor die hede as "vorläufige Ausserwirkungssetzung der feindlich dämonischen Gewalten".

Die oomblik wanneer die prediking die oorwinning in Christus stel, gaan daar 'n venster oop na en op die toekoms, na en op die eskaton. In die prediking moet hierdie 'eskatologiese venster' oopgemaak word! Dit bring nie alleen uitsig nie, maar ook ventilasie en vars lug in die bedompige sondige bedeling én geloofsontspanning te midde van die hoogspanning tussen die 'reeds' en die 'nog nie'. 
Die lewe in die tussentyd staan immers in die teken van stryd en aanvegting, van nood en bedreiging, van sonde en afdwaling. Die gemeente is in voortdurende beweging begrepe, in ' $n$ 'op weg wees', in 'n onophoudelike pelgrimstog, vol van spanning en onvolmaaktheid, in 'n duidelike 'nog nie'. Wel woon die Heilige Gees in die gemeente (vgl. 1 Kor. 6:19) en is daar deur die Heilige Gees nuwe lewe (vgl. Tit . 3:5), vryheid (vgl. 2 Kor. 3:17) en kindskap van God (vgl. Rom. 8:14; 1 Joh. 3:2). Die vervulling deur die Heilige Gees word egter nie voorgehou as 'n geslote en afgeslote ruimte nie, maar as 'n huis met gepaste vensters, as voortgang en beweging (vgl. Berkhof, 1968:100; vgl. ook Lemmer, 1987:159-182; Gaffin, 1988:43-52). Die lewe is 'n wedloop wat reeds begin het en waarin die oog gevestig/gerig moet wees op Jesus, die Leidsman en Voleinder, die Begin en Voleinder van die geloof (vgl. Heb. 12:2:

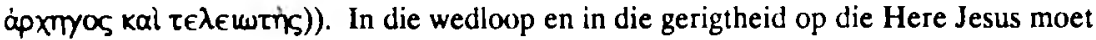
elke las afgegooi word, ook die sonde wat so maklik verstrik. Die prediking moet bou aan die geloofstamina sodat die wedloop - waarvan die einde en die oorwinning geen onsekerheid bied nie - met volharding gestry word.

Dit gaan dus in die prediking nie om 'n futuristiese en ook nie om 'n aanwesige eskaton in eksklusiewe sin nie. "Veelmeer ligt in de betrokkenheid van het 'nog niet' op het 'reeds' de karakteristiek van het leven der gemeente" (Berkouwer, 1961:144). Hierdic betrokkenheid vind sy mees markante uitdrukking wanneer Paulus 'n bepaalde 'reeds' ontken en 'n ander 'reeds' poneer: "Ek sê nie dat ek dit alles al het of die doel al bereik het nie, maar ek span my in om dit alles myne te maak omdat Jesus Christus my reeds Syne gemaak het" (Fil. 3:12).

So trek die sekerheid van die 'reeds' spore deur die lewe op weg na die toekoms. Dit gaan hierin nie om die mistroostigheid van die pessimisme of défaitisme nie, maar om die aktivering vanuit wat reeds ontvang en van wat beloof is.

In eskatologies gerigte prediking sal die 'reeds 'en die 'nog nie' nie teenoor mekaar in 'n teenstrydigheid staan nie, want dit is juis so dat in wat geskenk word, die uitsig op 'n nuwe volheid van realiteit van die erfenis gegee word (vgl. Pelser, 1986:37-46). Bowendien word die Heilige Gees aangedui as onderpand - 'n duidelike eskatologiese woord wat sowel die 'reeds' as die 'nog nie' omvat ( 2 Kor. 5:5: ßappaß̄̄u; 2 Kor. 1:22). Die Heilige Gees is die waarborg van die erfenis (vgl. Ef. 1:14). Dit is die Heilige Gees wat laat roep "Abba! Dit beteken, Vader" (Rom. 8:15) en Hy getuig met ons gees "dat ons kinders van God is" (Rom. 8:16).

Vanuit hierdie kindskap is daar tegelyk 'n uitsig op die toekoms. Nie alleen word daar vanuit die kindskap oor die erfenis en die verheerliking gepraat en gepreek nie (vgl. Rom. 8:17; Gal. 4:7); daar is ook nog die verwagting van die kindskap (vgl. Rom.

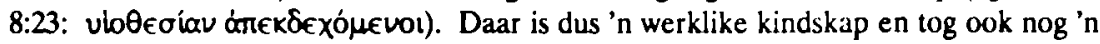




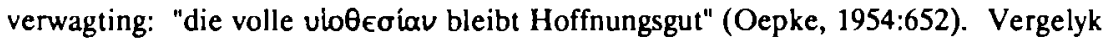
ook "die nog nie geopenbaar wat ons sal wees nie" (1 Joh. 3:2). In die prediking sal ook ten opsigte van die kindskap én die eskatologiese werklikheid gewerk moet word met die verwysing na volheid en volkomenheid. Voorts sal in die prediking sowel die 'reeds' en die 'nog nie' van die erfenis verkondig word. Juis dit plaas die prediking in 'n aktuele hoogspanning.

Ten opsigte van die hoogspanning waarin die prediking staan, moet dus konkluderend gesê word dat die bediening "heeft een finale, pleromatische kracht "Trimp, 1971:25). Die aktualiteit van die prediking is ten diepste gegrond in die teenwoordigheid van Christus deur die Heilige Gees. "The eschatological-pneumatheological perspective is the most salient theological perspective" (Lemmer, 1 987:175). Die praesentia Christi (vgl. Van der Walt, 1976:47-53) en die werking van die Gees is 'n absolute vereiste vir alle aktuele verkondiging. "Hier is die grens van die aktualiteit waarvoor ons telkens moet stilstaan. Dit is tegelyk sy krag. Daarsonder verval alle diens" (Müller, 1961:117).

\section{PREDIKING: ESKATOLOGIESE ALARMSINJAAL}

\section{$3.1 \quad$ Nee vir ódokoróa}

Die ganse struktuur van eskatologies gerigte prediking word in dreiging en vertroosting, in vertroosting en dreiging deur die erns, die laaste erns van wat kom, bepaal (vgl. Berkouwer, 1961:10). Een van die essensiële aspekte van die Christelike toekomsverwagting is hierin geleë dat die toekoms nie sonder meer as terra incognita te tipeer is nie. Alle eskatologie wat legitiem genoem kan word, is voortdurend besig met die uitsig op die Bekende, wat "ten tweede male" (Berkouwer, 1961:10) aanskou sal word deur hulle wat Hom as hulle heil verwag (vgl. Heb. 9:28). Die Godsryk het al gekom en is komende (in die hede) as saaityd, maar dit sal ook nog kom as oestyd. Die tyd van die oes is ook die tyd van die oordeel. Die mens is onderweg na ' $n$ toekoms waarin of die ewige lewe of die ewige oordeel op hom wag (vgl. Matt. 25:31-46; Op. 20:11-15; 21:7-8)

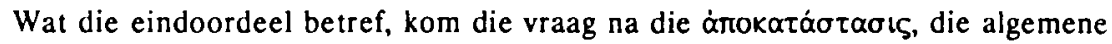
versoening, wel deeglik aan die orde en in die gesigsveld van die eskatologiese perspektief in die prediking. Dit is van besondere erns, omdat dit gaan oor die toekoms, die ewige lot van die mense. Daar is nouliks 'n vraagstuk van die eskatologie wat so duidelik en onmiddellik sy reperkussies het in die prediking, pastoraat en die sending. Dit is gelaai met ' $n$ besondere erns, die erns van die genade en die gerig van God (vgl. Berkouwer, 1963:203). Dit gaan naamlik oor die vraag of daar - in die verwagting van die geloof - gereken mag word op 'n algemene versoening, op die 
terugkeer van 'almal' tot die Vaderhuis met sy baie woninge. Kortom, dit gaan om die vraag na 'n uiteindelike, universele, onbegrensde triomf van Goddelike barmhartigheid en - indien die antwoord negatief is - of God dan nog as God van liefde verkondig kan word?

In die besinning hieroor gaan dit om dieper en ingrypender probleme as om dit af te maak met 'n verwysing na die Goddelike geregtigheid. Wat is die verhouding (parallel) tussen God se barmhartigheid en geregtigheid? Nie alleen die liefde van God nic maar ook die geregtigheid van God moet sy loop neem. In Skriftuurlike prediking gaan dit nie om 'n geïsoleerde liefde en om 'n opsigselfstaande geregtigheid wat elk sy eie weg gaan nie. "Liefde en trou sal mekaar ontmoet, geregtigheid en vrede sal mekaar omhels ..." (Ps. 85:11). Die sognaamde dualiteit tussen God se liefde en sy geregtigheid word duidelik deurbreek wanneer die geregtigheid van God en die liefde van God juis in die kruis geopenbaar word.

Is die konkrete inhoud van God se almag en liefde - die bewys van sy genade en barmhartigheid - nie daarin gelee dat dit eenmaal sal blyk, in die finale onthulling en vervulling van alle dinge, dat alle mense tog deel sal kry aan die gerig as heil nic? Dic antwoord hierop is beslis en duidelik ontkennend. "God se gerig as onheil is juis 'n gestalte van sy triomferende geregtigheid" (Heyns, 1978:411). Die genadetyd loop uit en ten einde. By die eindgebeure in die finale oordeelsdag sal geen geleentheid vir berou of bekering gegee word nie. Dit sluit nie uit nie dat genadetyd al in hierdie bedeling verstryk: "Daar was vir hom (Esau) geen moontlikheid om die saak reg te stel nie" (Heb. 12:17).

Die onheil van die goddelike gerig sal die wat nie in Christus voor die gerig staan nie, tref. Hulle sal vir ewig in hulle ongeloof gefikseer word as mense wat God se genade. verwerp het. "Daar (is) geen offer meer wat ons sondes kan wegneem nic. Daar bly alleen 'n verskriklike verwagting oor van oordeel en gloeiende vuur wat die teenstanders van God sal verteer" (Heb. 10:26-27). Dit sal "n rampsaligheid wees wat deur geen mensewoorde beskrywe, en deur geen menseverstand begryp kan word nie (vgl. Matt. 7:13, 25:30; Mark. 9:44; 2 Tess. 1:9; Op. 14:11). Hulle sal God se verwerping vir ewig moet dra en sy liefde vir ewig moet ontbeer, omdat hulle Jesus Christus, Verlosser van die wêreld, nie in die geloof wou aanvaar nie.

\subsection{Prediking: preludium op ewige cordecl en genade}

In die lig van die naderende oordeel gesien, is die verkondiging van die heil van God in Christus en die oproep tot geloof in Hom 'n wekroep en alarmsirene wat afgaan in hierdie lewe. Vanuit die verterende liefde van God klink die waarskuwing van die 
eskatologiese "brandgevaar'. "Ek ly verskriklik in hierdie vuur" (Luk. 16:24) roep die ryk man "toe hy in die doderyk in pyn verkeer" (vs. 23). In antwoord op sy hulpgeroep word 'n regstreekse en konkrete verband gelê met die prediking: "Hulle het die woorde van Moses en die profete. Laat hulle daarna luister" (vs. 29). Die verband met die geopenbaarde Woord word in so 'n mate eksklusief en uniek aangedui dat "as hulle na Moses en die profete nie luister nie, sal hulle nie oortuig word nie al sou iemand uit die dood opstaan" (vs. 31).

Prediking is dus God se alarm wat afgaan in hierdie wêreld. "Maak jou klaar om voor jou God te verskyn!" (Am. 4:12). Prediking is die aankondigende "brandgevaar'-waarskuwing: "die dag kom en hy brand soos 'n oond" (Mal. 4:1). "De preek is praeludium op het eeuwig oordeel dat komt" (Kuyper, vgl. Van Ruler, 1953:93). Prediking is hierin ook genademiddel, want "Het is een feit, dat de wereld niet ongewaarschuwd geoordeeld zal worden, en vooral het oordeel, dat bij het Huis Gods begint, komt nooit onverwacht" (Luthi, 1948:104). Dit is God se onveranderlike goedheid en barmhartigheid wat nie wil dat die mens in die verderf gly nie en wat voor die dag aanbreek nog die geleentheid tot besinning en bekering skenk. Wanneer dit selfs in die gewone lewe gebruiklik is "om voor vervaldagen waarschuwingen te verzenden, zou dan God, die de mensen schiep, in Zijn oordelen onmenselijk zijn?" (Luthi, 1948:105). God wil spaar en red. Daarom sê hy by monde van sy profeet Maleagi (4:2): "Maar vir julle wat eerbied het vir my Naam sal die son van redding skyn met genesing in sy strale." En hieraan word dan weer die prediking verbind: "Onthou die wet van my dienaar Moses, die voorskrifte en die bepalings wat Ek aan hom by Horeb gegee het ..." (Mal. 4:4).

Gerigs- en oordeelsprediking is dus nie negatief nie. Dit het 'n sterk positiewe kant. Dit is nie vreesaanjaende prediking nie; dit is verlossingsprediking. Floor (1979:43) toon aan dat die Hebreeuse wortel van die Griekse woord vir oordeel die betekenis het van "om door middel van het gericht genade en barmhartigheid te bewijzen". Genade en gerig is dus twee kante van eg profetiese verkondiging. Daarom is die oordeel wat in die prediking moet meeklink "een bijbelse resonans op die evangelie as goeie boodskap van genade" (Floor, 1979:12).

Besinning oor die eskaton laat die geloofspanning, die roepstem en die verantwoordelikheid geen oomblik buite beskouing nie. Die evangelie spreek nie oor die gerig om teoreties te oriënteer oor die onveranderlike feitelikhede nie. Prediking laat nie die mens (wat met die eskaton gekonfronteer word) toe om neutraal en objektief daarteenoor te staan nie - dit vereis aktivering van sy hele lewe. Die gerig lê eksklusief in die hand van Jesus Christus (Joh. 5:22,23) en in die boodskap bly die situasie oop en word dit nie vanuit 'n a priori toegesluit nie. In die evangelie word oor die eskaton eksklusief in en vanuit die pelgrimsituasie, die nog op weg wees, gespreek. 
Dit is die waarskuwingskarakter tot ' $n$ interpretasie-sleutel, naamlik dat die eskaton ter sprake kom in onlosmaaklike verband met die prediking van die heil van God (vgl. Berkouer, 1963:207).

Afwysing van die leer van die órokordóraors veronderstel dus ' $n$ ander wyse van besig wees met die eskatologie deur naamlik te poneer dat die prediking van die eskaton betrek moet word op die geloof, sodat nie objektief-teoreties en neutraal nie, maar alleen in die sfeer van geloof en verantwoordelikheid met die eskaton besig gebly word.

\section{$33 \quad$ Prediking is universeel gerig}

Meermale kom die universele gerigtheid van die prediking nie voldoende tot sy reg nie. Dit gaan in die heilsboodskap nie maar om die mededeling van 'n kondisionele reêl nie, naamlik dat indien iemand glo, sal hy behou/gered word. Die Skrif praat van 'n belofie. Dit gaan dus om 'n ernstig bedoelde roep tot die verkondigde heil, wat in die prediking op die een of ander reële wyse binne almal se horison gebring moet word. Vir sover dit die wyse aangaan waarop Christus se doel vir die mens bereik is, lê die Nuwe Testament nooit enige beperking op die omvattendheid (inhoud)en universaliteit (gerigtheid) van die doel wat bereik is nie. Die feit dat almal nie salig word nie, vind nie sy grond in die wyse waarop Christus die eskaton bereik nie. Hy sluit nie doelbewus spesifieke mense uit nie maar Hy sluit uit genade spesifieke verdienstelose sondaars uit genade in (Dordtse Leereëls 1,10; Joh. 6:39). Paulus kan heel onbevange se dat "Hy deur Hom alles met Homself sou versoen ... die dinge op die aarde sowel as die dinge in die hemel" (Kol. 1:20), én "dat God in Christus die wêreld met Homself versoen het" ( 2 Kor. 5:19), én, "Christus Jesus wat Homself gegee het as 'n losprys vir almal" (1 Tim. 2:6). Christus wat in die evangelieverkondiging aangebied word, roep almal in alle erns (Dordtse Leerreëls, III en IV,8,9) omdat sy versoening genoegsaam is vir elkeen.

Wie dus nie ten volle sou erken wat vir God aangenaam is nie, naamlik dat die geroepenes in die geloof tot Hom kom, sou tot die konklusie moes kom dat die geloof 'n kreatiewe aard het en 'n situasie skep wat nie aanwesig is nie, maar deur die geloof daargestel word. So 'n konklusie is 'n totale wanvoorstelling. Wie die verkondiging van die beil verswak deur ' $n$ "meritoriale of creatieve geloofsopvatting" (Berkouwer, 1963:217-218), tas die deurdringende erns van die prediking aan. "Creative preaching is creative (exclusively - toegevoeg) because it is the tool of the creative and recreating God" (Achtemeier, 1980:11).

Die evangelie gaan in die prediking tot almal uit - dit mag en moet - en dan in die volle 
sin van die woord as blye boodskap. Daar lê in die daad van God in Jesus Christus 'n gerigtheid op die wèreld, op almal, waardeur dit sinvol word dat die ernstige roepstem uitgaan tot almal sonder onderskeid (vgl. Matt. 28:19; ook 24:14). Dit kan nie die bedoeling wees dat die heilsverkondiging tot almal uitgaan en dat tog eintlik nie 'almal' bedoel word nie, maar slegs "electi" (Berkouwer, 1963:218), terwyl die ander slegs geroep sou word tot 'n daad van geloof en bekering wat geen 'waaragtige' en 'aanwesige' betekenis het nie. Dit sal 'n diep ingrypende devaluasie van die 'evangelie' en evangelieverkondiging beteken.

As die prediking dan wel 'n eskatologiese alarm laat afgaan, is dit nie alleen vanweë Christus vir ons nie, maar ook op grond van die ander modus van Christus, naamlik Christus in ons (vgl. König, 1970:284-285). Dan geld dat dié wat "in Hom glo" (Joh. 3:16) in Hom bly (Joh. 6:56) en daarom nie verlore sal gaan nie maar die ewige lewe in (Joh. 3:16) hulleself het. Die beperkende of uitsluitende aard van die eskaton vind sy grond dus nie in die doel wat deur Christus vir ons bereik is nie. Die beperking kom wanneer die mens se verantwoordelikheid tot geloof aktief betrek word. Die mens, en nie God nie, dra dus die verantwoordelikheid vir elke uitsluiting deur die eskaton. Dit is hieroor dat die eskatologiese alarmsinjaal in die prediking moet afgaan omdat God nie wil hê "dat sommige in die oordeel moet vergaan nie, maar dat almal tot bekering kom" (2 Pet. 3:9).

\subsection{Eskatologie en empirie}

Die eskatologiese alarm van God gaan af oor die volle spektrum van die lewe. Die eskatologiese vermaning staan so dig by die gewone lewe dat dit hom van alle bespiegelinge en spekulasie distansieer. In duidelike woorde word die erns van die beslissing met verantwoordelikheid, midde in die lewe aangedui. Dit gaan nie om 'n abstrakte isoleerbare 'glo' of 'nie-glo' nie, maar in geloof en ongeloof in konkrete vorme en dade, byvoorbeeld in die "dwaas sê vir jou broer" (Matt. 5:22), in die verlei word tot sonde deur jou regteroog of regterhand, (vgl. Matt. 5:29; 18:9) of in die weiering van barmhartigheid: 'n beker (koue) water (vgl. Matt. 25:41-46). Dit alles word eksplisiet met die eskaton in verband gebring, in 'n deurdringende erns wat alles met die leue en niks met moralisme te maak het nie.

In die eindoordeel sal dit gaan oor die geleéfde beslissing en hoeseer die beslissing teenoor Christus die ganse lewe omspan. Vanuit die eskatologie handel die prediking nie maar oor 'n moralistiese slotakte van die geskiedenis nie. As Christus, die Eskatos, loodreg op die tyd staan (regstreeks in die geskiedenis werk) vanweë sy praesentia realis, dan het dit dié implikasie dat die prediking "n saak is vir en van "sakboekies" omdat geloof sulke daaglikse beslissings verg, maar ook van "kalenders", waarin die 
maande en die jare belangrik word (vgl. Smit, 1987:68,74).

Die vraag mag gestel word: waarin het hierdie onverwagte erns sy fondament? Die fondament lê nie in 'n menslike legalisme of moralisme wat meermale sulke radikale en ernstige allures kan aanneem nie, maar in die realiteit van die evangelie. Hierdie evangelie bring die buitenste duisternis ter sprake. Teen die agtergrond van die verderf verrys die kruis (vgl. Fil. 3:19). Die nie-ken-van God beteken ongehoorsaamheid aan die evangelie van Jesus Christus (vgl. 2 Tess. 1:8).

In die diskussie oor die ájokatáotaols dring die vraag hom ook op: waarom word die prediking van die blye boodskap verbind met so 'n ernstige en dringende waarskuwing? Word die evangelie met sy radikale en dringende waarskuwing nie daardeur gerelativeer nie? Kom alles ten slotte nie maar weer in die hande van die mens wat sy eie beslissinge neem nie? Dit is hierdie vrae wat altyd 'n enorme rol gespeel het in die besinning oor die verhouding tussen die genade van God en die menslike beslissings-

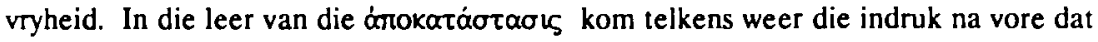
die dringendheid van die menslike beslissing vervaag in die stralende lig van die triomfantlike genade: gratia irresistibilis. Is die keuse hier nie 'n dilemma nie, naamlik

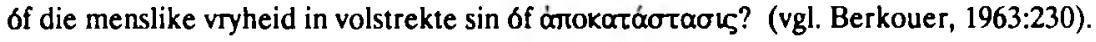

Die evangelie ken egter nie so 'n skynbaar onontwykbare dilemma nie. Allereers weet die gelowige wel van 'n eie keuse en van 'n eie beslissing, maar hy is tegelykeryd ook daarvan deurdronge dat hierdie beslissing "een capitulatie, een ontvangen, een zich gegrepen weten" beteken (Berkouwer, 1963:30). Die appèl in die prediking tot geloofsbeslissing aksentueer die volheid van die heil as God se gawe.

In die prediking het die prediker ook te make met die moontlikheid van ' $n$ teenreaksie aan die ontvangkant, 'n teenreaksie teenoor die verkondigde heil, naamlik dié van die ongeloof. Hierin lê die diepste problematiek van die leer van die órokatáơtaơ evangelie maak hierdie ongeloof nie irrelevant nie, en daarom ook nie die verkondiging van die evangelie nie. Inteendeel, met die diepste erns moet die prediking daarteen waarsku.

Wat hierdie waarskuwing betref: in die toon van die waarskuwing moet gehoor word vanuit watter agtergrond die waarskuwing klink. Dit gaan in die waarskuwing om 'n weerhouding van die duisternis sodat die mens die duisternis nie bo die lig verkies nie. Dit is uitsluitlik die konteks van alle waarskuwings wat in verband met die evangelie uitgaan. As die gerig ter sprake kom, dan is dit teen die agtergrond van die rykdom van die goedertierenheid, verdraagsaamheid en lankmoedigheid van God. Teen hierdie agtergrond word gewaarsku teen die uitbly van die boetvaardigheid (vgl. Rom. 2: 16). Die erns van die evangelie word sigbaar wanneer geen erns gemaak word met die 
verkondigde heil nie (vgl. Heb. 2:13).

\subsection{Oordeelsprediking: 'n newegevolg van genadeverkondiging}

Daar is 'n radikale breuk tussen die evangeliese dreiging en elke onevangeliese terreur wat wel "verschrikkelijk, maar niet echt-ernstig kan zijn en elk waarachtig appèkarakter mist" (Berkouer, 1963:231). Die evangeliese verwysing in die prediking na die gerig - dat die Here te vrese is (vgl. 2 Kor. 5:11) - is 'n besonder gekwalifiseerde dreiging omdat dit die keersy is van die uitnodiging en van die oorvloedige rykdom waarvan die kerugma-prediking getuig. Die erns van die waarskuwing kan nie afgelees word uit die wyse waarop die gerig uitgebeeld word as skrikaanjaende realiteit nie, maar is slegs vanuit éen kriterium te onderken, naamlik aan die verband met die evangelie. Die oordeel is 'n "nevengevolg" (Th. Zanen, vgl. Floor, 1979:53) van die optrede van Jesus tot redding van die mens; dit is 'n "begeleidingsverschijnsel" (Floor, 1979:131) van God se verlossing. "Eternal damnation is related to eternal blessedness as the negative to the positive" (Quistorp, 1955:186). Die ontstellende werklikheid van God se oordeel word deur Jesus Christus as die eskatos volvoer; dit is die eskatologiese voltrekking van die regverdige dreigement van sy evangelie.

Die verkondiging van Christus se oordeel is veral sterk gekoppel aan sy opstanding. Hy is die Eersgeborene uit die dood en Hy sal weer kom om te oordeel. Die opstanding van Christus is die "Stunde aller Stunden" (Stählin, 1942:1106). In Handelinge 2 verbind Petrus die opstandingsprediking met die gerigsprediking. "De opstandingsboodschap is eigenlijk een ontzettende boodschap" (Floor, 1979:93). Dit is die aankondiging dat die dood oorwin is, ja, maar ook dat die oordeel kom, want die opgestane is ook die Regter.

Die gerig van God wat in die toekoms sal plaasvind, plaas dus 'n swaar aksent op die opstandingsprediking in die hede om die mens in die hede op te roep tot bekering. Hierdie oproep met die oog op die komende gerig kom dan ook sterk uit as 'n "alarmsinjaal" (Floor, 1979:63) in die prediking van Petrus (vgl. Hand. 2:38,40; 3:19-20,26; 10:42) en by Paulus (vgl. Hand. 13:40; 17:30-31). Juis hieroor skryf Paulus ook dat "die liefde van Christus dwing ons, omdat ons tot die insig gekom het dat een vir almal gesterwe het (2 Kor. 5:14).

In die prediking moet die liefde en die toegang (vgl. Heb. 10:19 e.v.) wat daar in Christus Jesus is, dus verkondig word - 'n liefde en toegang wat die weg baan tot vrymoedigheid om tot God te nader met 'n opregte hart en met volle geloofsekerheid (vgl. Heb. 10:22). "Ons weet nie wat kom nie, maar ons weet Wie kom. Hy aan wie die laaste uur behoort, hoef die volgende minuut nie meer te vrees nie" - (Thielicke, 
1977:15). Die oordeel sal daarom nie alleen verskrikking nie maar ook bevryding beteken (vgl. Matt. 25: daar is ook die 'skape' aan die regterkant). Die belang en aktualiteit van die prediking is dat die maatstaf waarvolgens geoordeel sal word, opregte geloof in Christus is. "Wie in Hom glo, word nie veroordeel nie; wie nie glo nie, is reeds veroordeel omdat hy nie in die enigste Seun van God glo nie. En so kom die skeiding ..." (Joh. 3:18-19).

Vir die prediking het dit konsekwensies. Dit moet verkondiging wees met "vrees en bewing" (vgl. Fil. 2:12) - verkondiging van die blye boodskap aan die wye wêreld dat God die wêreld so lief gehad het ... (vgl. Joh. 3:16). Dit is prediking in die gees van: "my siel herdink met sidderbewe hoe God, met majesteit beklee, deur wolke en donkerheid omswewe, sy wet op Horeb het gegee" (Skrifberyming 26:1). Die risiko van die toekomsverwagting, "de eschatologische crisis" (Berkouwer, 1961:196), moet in die prediking gehanteer word deur te verkondig dat die toekoms hóópwekkend is deurdat die oordeel en verwerping deur Christus weggeneem is, maar tegelyk ook angswekkend naby gekom het, want "hoe sal ons dan ontkom as ons so 'n groot saligheid verontagsaam het?" (Heb. 2:3). Die verwerping in die komende gerig is presies wat God nié wil hè nie en waarvoor die prediking as 'eskatalogiese alarm' wil bewaar. "Wie deze donkere ondertoon wegneemt, tast de ernst en het respect aan waarmee God in zijn liefde op ons mensen ingaan" (Berkhof, 1968:57).

Daar is so iets soos 'n onevangeliese prediking oor die 'hel'. Dit is wanneer dit geskied op 'n wyse wat meer psigologiese effek beoog as wat dit waartik evangelies is. Om vreesaanjaend oor die temperatuur en die 'hel' van die hel te preek, is vanself 'n terreur op die mens, maar die evangelie klink nie daarin deur nie. Dit is een van die ernstigste doolweë waarin die prediking kan beland. Vanuit die eskatologiese eindgerig sal die prediking wel terdeë aksent lè op die risiko-sy van die toekomsverwagting. Die dringendheid en die erns van die waarskuwing van die naderende Eskatos sal egter nooit die aard van terreur hê nie, maar sal die dringende uitnodigende stem van die Goeie Herder wees wat sy skape oppas en teen gevaar wil vrywaar. Buite dié verband om verskrompel elke woord tot onverstaanbare sinloosheid. "The vital point of all teaching, of theology, and of the whole Bible is to bring us to a knowledge of Him and into relationship with Him" (Lloyd Jones, 1973:329).

Waar die gerig van God in die prediking nie tot sy reg kom nie, ontbreek die waarskuwingselement. God se reg kry nie die aksent wat dit behoort te hê nie en die verantwoordelikheid en skuld van die mens ewe min; "hel en hemel in hun felle tegenstelling schijnen te verbleken en het getal van de gerusten in Sion wordt groot" (Kremer, 1976:135). Sulke prediking is skromelik eensydig en laat die volk van God in die steek. 
Die eensydigheid is daarin geleë dat die toekoms nie geïntegreerd in heilsperspekticf én beslissingsperspektief gestel word nie. Christus Jesus is die Gerigsdraer, die Redder, ja, maar Hy is ook die Gerigsvoltrekker, die Regter.

Prediking oor die liefde van God en die 'konsekwensies' daarvan buite die evangelie om, is gevaarlik en oorskry die grens van die prediking. Christus Jesus, die Here, in sy eenheid met en sy onderskeiding van die Vader en die Gees, moet verkondig word (vgl. Le Roux, 1990:1-298) en nie dreigemente oor die hel en gerig nie. Dié kom wel aan die orde as synde die konsekwensie en keersy wanneer die verkondigde Christus nie in die geloof omhels word nie. Die moontlikheid van 'verlore kan gaan,' is 'n konsekwensie van die beslissingskarakter van die evangelie hoewel die evangelie allereers 'n heilskarakter het.

Dus is die kernpunt van die prediking nie die verkondiging van "de terzijdestelling van het recht en het oordeel Gods" nie (Kremer, 1976:137), maar verkondiging dat God self op 'n ondeurgrondelike wyse sy reg en oordeel oor die gevalle mens gehandhaaf het. Hieraan is deur Christus voldoen en dit het die versoening gebring. Dit is ware eskatologiese gerigsprediking! "Pas op, moet Hom wat met julle praat, nie afwys nie. Hulle wat Hom afgewys het toe Hy sy Goddelike woord op aarde laat hoor het, het nie ontkom nie. Hoeveel minder sal ons ontkom wanneer ons nie ag slaan op Hom wat van die hemel af met ons praat nie?" (Heb. 12:25).

\section{RIGLYNE}

- Prediking: die viva var van die Deus loquens

In die prediking moet die lewende stem van die sprekende God gehoor word. Prediking is daarom nie 'n histories-argeologiese in herinnering roep van 'n vasstaande metafisiese dokument nie, maar 'n dinamies-lewende heilsaktiwiteit van God self. Deur die Woord - daadwoord, Dabar - werk God deur die geskiedenis heen. Daarom is prediking 'n profeties eskatologies-keurende proklamering. Dit is hierdie dinamiese daadkrag van die Woord as ewige Logos wat die prediking 'red' van gearriveerdheid en daarvan 'n onrustige aktiwiteit maak. Dit plaas die prediking in 'n hoogspanningstroom met 'n angsvolle polariteit tussen die proton en die eskaton. Die in-mekaar-gryp van die proton en die eskaton, die oormekaar-skuif van die aeone vanweë die dinamies-eskatologiese kragontplooing, skep 'n hoogspanningstroom wat deur die transformator van die prediking gaan.

- Prediking: 'n eskatologies plus

Prediking as draer van die hoogspanningstroom van die lewende Woord van God 
met sy blye boodskap van die reeds reële triomf in Christus, dra in hom 'n eskatologiese plus, 'n visie op die finale triomf, "die oog gerig op Jesus, die Leidsman en Voleinder van die geloof' (Heb. 12:2). Hierdie eskatologiese plus, in 'n wêreld met sy minusse, plaas die prediking in 'n eskatologiese hoogspanning. Prediking kan dus nie 'n geslote of afgeslote ruimte wees nie, maar is in 'n deurlopende pelgrimstog vol spanning en onvolmaaktheid, saam met die gemeente in 'n voortdurende beweging en voortgang onderweg na die toekoms.

- Prediking: transformator van eskatologiese hoogspanning

Die eskatologiese verwagting vanuit die reeds geskonke depositum in Christus deur die Gees van God, bou 'n hoogspanning in die prediking in. Dit verleen aan die prediking 'n stimulerende aktualiteitsgraad met verrykende effek vir die alledaagse lewe. Die 'hoogspanningstroom' van die eskaton gaan deur die 'transformator' van die prediking - as 'reaktor' en opwekker tot 'n lewe coram Deo - die lewe in.

- Prediking: eskatologiese alarm

Prediking is 'n eskatologiese alarm. Vanuit die verterende liefde van God klink die waarskuwingsirene van die eskatologiese 'brandgevaar': "die dag kom en hy brand soos 'n oond" (Mal. 4:1). Die genadetyd loop eenmaal finaal uit en af in die eindgerig; daarom die alarm van die Woordverkondiging met sy oproep tot

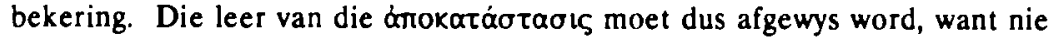
alleen die liefde en die genade van God nie maar ook die geregtigheid van God spreek in die eindoordeel.

- Prediking: alarm van genade én gerig

Gerigsprediking is genadeverkondiging want Christus is die Gerigsvoltrekker én die Gerigsvoldoener. Prediking wat die gerigsalarm laat afgaan, is dus nie gemik op 'n psigologiese effek nie; dit is 'n besonder gekwalifiseerde 'dreiging' deurdat dit die keersy van die uitnodiging tot geloof in Christus stel, naamlik die verwerping van die uitnodiging en van die oorvloedige rykdom waarvan die kerugma-prediking getuig (Joh. 6:53-54). Dit is nie 'n alarm sonder meer nie. Dit is 'n alarm wat opklink vanuit die genade van God. Daar is maar één kriterium naamlik die evangelie: "... die liefde van Christus dwing ons .." (2 Kor. 5:14). Die liefde van God, en nie die temperaturur van die hel nie, is die gloed en hitte van die prediking.

- Prediking: 'n eskatologiese heils- en beslissingsboodskap

Die eskatologiese verwagting staan gelyktydig in 'n heils- én beslissingsperspektief. 
Daarmee is die prediking gekwalifiseer as heilsboodskap maar tegelyk ook getipeer as appellatiewe verkondiging wat roep tot bekering en 'n beslissing afdwing.

- Prediking: 'n eskatologiese appel in en op die hede

Die Woord wat op die jongste dag oordeel is dieselfde Woord wat nou reeds oordeel. Die krisis, die oordeel en die sifting wat in die eindoordeel voor die regterstoel van Christus openlike beslag kry, is deur die verkondiging in die hede al aan die werk en geaktualiseer deur die verkondiging van Christus in Wie die oordeel - en daarmee die krisis - saamgetrek is (Joh. 3:18; Hand. 17:31). Dit gee aan die prediking besondere aktualiteit deurdat dit oproep om elke dag coram Deo te lewe. Wie hierdie appèl veronagsaam, kom in 'n onheilsituasie coram Deo te staan.

- Prediking van die finale eskaton dra 'n eksistensiēle karakter

Prediking van die beloofde toekoms is prediking wat die mens in die diepste wese aanspreek en in sy volle bestaan raak en daar aandring en appelleer op beslissings in verband met en vanuit wat kom. Prediking van die finale eskaton dra dus altyd 'n eksistensiële aard en laat nie vryblywende objektiwiteit toe nie. Dit is prediking wat God se oordeel hier en nou aanse. Dit is om die eindgerig in die hede in te preek en die toekoms nie as terra incognita te tipeer nie, maar om die uitsig op die Bekende wat vir die tweede maal kom, te verkondig

- Prediking: 'n eskatologiese krisis

Die verkondiging van Christus as die Eskatos genereer 'n eskatologiese krisis, want die prediking van die eskatos kondig die bestaan van die oordeel van God aan en stel terselfdertyd hierdie oordeel in werking. In die oordeel wat Christus bring, word inderdaad 'n skeiding voltrek ... tussen gelowiges en ongelowiges (Joh. 3:1617). Die eskatologiese krisis wat die verkondigde evangelie stel, is die newegevolg en begeleidingsverskynsel, naamlik dat wie die evangelie verwerp, in die oordeel van God sonder begenadiging sal staan.

- Prediking: preludium op die eskatologiese eindoordeel

Prediking as verkondiging van God se liefde en genade in Christus het as keersy en newegevolg dat wie die liefde en genade verag en verwerp, veroordeel staan. Daarom is prediking 'n oproep tot bekering en gevolglik altyd voorwaardelik in sy verkondiging van die oordeel. So word die prediking van God se oordeel en genade preludium op die ewige oordeel wat finaal sal kom. Die gerig wat kom is 'n toekomstige realiteit maar tegelyk 'n teenwoordige werklikheid. In die prediking moet beide aspekte verdiskonteer word. Die eindoordeel sal niks minder wees nie as bevestiging en bekragtiging van die evangelie en die suiwere 
verkondiging daarvan. Aan die prediking stel dit die geweldige opgaaf dat die Woord van God in sy oordeel en genade so verkondig moet word dat Christus Homself daarmee vereenselwig.

\section{BIBLIOGRAFIE}

ACHTEMEIER, E. 1980. Creative preaching: finding the words. Nashville : Abingdon Preachers' Library.

BERKHOF, H. 1968. Gegronde verwagting: schets van een Christelijke toekomstleer. Nijkerk : Callenbach.

BERKOUWER, G.C. 1961. De wederkomst van Christus. Deel I. Kampen : Kok. (Dogmatische Studiēn).

BERKOUWER, G.C. 1963. De wederkomst van Christus. Deel Il. Kampen : Kok. (Dogmatische studien).

BERKOUWER, G.C. 1967. De Heilige Schrift. Deel I. Kampen : Kok. (Dogmatische Studiën).

BINGLE, P.W. 1986. Taal en ver-taal in die prediking: die homiletiese funksie van taal in die prediking as 'n kommunikasiegebeure. Potchefstroom. (Verhandeling (Th M) - PU vir CHO.)

BINGLE, P.W. 1988. Coram Deo: die betekenis van die eskatologie vir prediking. Kaapstad. (Proefskrif (Th. D.) - PU vir CHO.)

DELLING, G. 1938. kainos TWNT III.

DOUMA, J. \& VAN DER VEGT, W.H. s.a. Het gepredikte Woord. Preeken van Johannes Calyyn. Deel I. 2de druk. Franeker : Wever.

FLOOR, L. 1979. Het gericht van God volgens bet Nieuwe Testament. Amsterdam : Buijten \& Schipperbeyn.

GAFFIN, R.B. 1988. The Holy Spirit and eschatology. (In Wethmar, CJ. \& Vos, CJ.A. reds. 'n Woord op sy tyd. Pretoria : NG Kerkbockhandel. p. 43-52).

HE YNS, JA. 1973. 'n Teologie van gehoorsaambeid - ontwerp van 'n eietydse teologie. (In Bakker, J.T., Hartvelt, G.P., Kuitert, H.M. \& Meulman, G.E., reds. Septuagesimo Anno. Theologische opstellen aangeboden aan prof. dr. G.C. Berkouer. Kampen : Kok. p. 74-85.)

JONKER, H. 196-. De prediking als polair gebeuren. (In Jonker, H. ned Actuele prediking. Nijkerk : Callenbach. p. 11-152)

JONKER, H. 1962 Liturgische oriêntatie: gesprekken over de eredienst. Wageningen : Zomer \& Keuning.

KÖNIG, A. 1970 . Jesus Christus die Eschatos: die fundering en struktuur van die eskatologie as teologiese Christologie. Pretoria : NG Kerkboekhandel.

KONRAD, J. 1963. Die evangelische Predigt. 2. Aufl. Bremen : Schünemann.

KREMER, W. 1976. Priesterlijke prediking. (Een bundel eigen werk, verzameld en aangeboden ter gelegenheid van zijn gouden ambtsjubileum. ) Amsterdam : Bolland..

LE ROUX, J. 1990. Die betekenis van die verhouding in die Goddelike Drie-eenheid vir die prediking. 'n Homiletiese ondesock vanuit Johannes 14 to 16. Potchefstroom. (Proefskrif (Th.D.) - PU vir CHO.)

LEMMER, H.R. 1987. Reciprocity between eschatology and pneuma in Ephesians 1:3-14. New Testamentica, 22(2):159-182.

LLOYD-JONES, D.M. 1973. Studies in the Sermon on the mount. Volume 2. London : Inter-varsity.

LOUW, DJ. 1984. Teolologie in hoop. Kaapstad : NG Kerk-Uitgewers.

LUTHI, W. 1948. De zeven gesprekken van Maleachi. Francker : Wever.

MŪLLER, BA. 1961. Die lewende Woord aan die mens in die hede. Zaandijk : Heijnes. (Procfskrif (Th.D.) - VU.)

NüRENBERGER, K. 1987. The eschatotogy of marxism. Missonalia, 15(13):105-109. 
OEPKE, A. 1954. pais. TWNT V.

PELSER, G.M.M. 1986. Resurrection and eschatology in Paul's letters. New Testamentica, 20:37-64.

QUISTORP, H. 1955. Calvin's doctrine of the last things. London: Butterworth.

RIDDERBOS, H. 1966. Paulus: ontwerp van zijn theologie. Kampen : Kok.

SCHMIDT, W.H. 1987. Ansätze zum Verstehen des Alten Testaments. Evangelische Theologie, 47/42:436-459.

SMIT, D. 1987. Die geloof is dan ... Kaapstad : Lux Verbi.

SNYMAN, WJ. 1977. Nuwe en oue dinge: 'uit die skat van die koninkryk'. Potchefstroom : Pro Rege.

STÄHLIN, G. 1942. nun TWNT IV.

THIELICKE, H. 1977. Die Christen in 'n krisis: 'n boek van boop. Kaapstad : Tafelberg.

TRIMP, C. 1971. De actualiteit der prediking: in het licht van het 'Sola Scriptura' der reformatie. Groningen : De Vuurbraak.

TRIMP, C. 1986. Heilsgeschiedenis en prediking. Kampen : Van den Berg.

VAN DER WALT, JJ. 1976. Christus as Hoof van die kerk en die presbiteriale kerkregering. Potchefstroom : Pro Rege.

VAN DER WALT, JJ. 1989. Teologiese tipologie: 'n Homiletiese sleutel vir die prediking van die Ou Testament. In die Skriflig, 25(89):53-61, Maart.

VAN ROOY, H.F. 1988. The eschatology of Haggai. Old Testament Essags. New Series, 1(1):49-63.

VAN RULER, A.A. 1953. De grenzen van de prediking. Kerk en theologie, 4:8497.

VAN WYK, J.H. 1986. Gesindheid en gestalte. Pretoria : NG Kerkboekhandel.

VERSTEEG, J.P. 1971. Christus en de Geest. Kampen : Kok.

WESSELS, G.F. 1987. The eschatology of Colossians and Ephesians. New Testamentica, 15(13):105109. 
62 